\title{
Applying best practices to pregnant women in the obstetric center
}

\author{
Boas práticas aplicadas às parturientes no centro obstétrico \\ Buenas prácticas aplicadas a las parturientes en el centro obstétrico
}

\section{Bianca da Costa Vieira' \\ ORCID: 0000-0002-5567-5502 \\ Marli Terezinha Stein Backes' ORCID: 0000-0003-3258-359X \\ Lediana Dalla Costa" ORCID: 0000-0002-9114-3669}

Vanessa Martinhago Borges Fernandes' ORCID: 0000-0002-0552-7229

Heloísa Helena Zimmer Ribas Dias' ORCID: 0000-0002-1744-7904

Dirce Stein Backes"'I ORCID: 0000-0001-9447-1126

'Universidade Federal de Santa Catarina. Florianópolis, Santa Catarina, Brazil.

"Universidade Paranaense. Francisco Beltrão, Paraná, Brazil.

"'Universidade Franciscana. Santa Maria, Rio Grande do Sul, Brazil.

How to cite this article:

Vieira BC, Backes MTS, Costa LD, Fernandes VMB, Backes DS. Applying best practices to pregnant women in the obstetric center. Rev Bras Enferm. 2019;72(Suppl 4):191-6. doi: http://dx.doi.org/10.1590/0034-7167-2018-0422

\section{Corresponding Author Lediana Dalla Costa \\ E-mail: lediana@prof.unipar.br

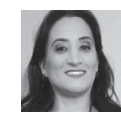

Submission: 06-12-2018

Approval: 09-23-2018

\section{ABSTRACT}

Objective: To identify the meaning attributed by nursing technicians to good care practices based on scientific evidence used with the pregnant women during the dilation stage of labor. Method: A qualitative study, based on Grounded Theory principles. Twelve interviews with nursing technicians attending labor in the obstetric center of two public hospitals, in Florianópolis/SC, were performed, from August of 2016 to March of 2017. Data were analyzed using open, axial coding. Results: The implementation of good practices, for nursing technicians, means adequately performing their activities, providing humanized care to the pregnant woman, respecting her autonomy, promoting pain relief, and a peaceful labor. Final Considerations: An adequate number of technicians must be determined to maintain quality of care, and to complete nursing records in a more detailed and systematized manner. Descriptors: Birthing Centers; Obstetric Nursing; Humanizing Delivery; Labor, Obstetric; Humanization of Assistance.

\section{RESUMO}

Objetivo: Identificar o significado que técnicos de enfermagem atribuem às boas práticas de cuidado baseadas em evidências científicas aplicadas às parturientes durante a fase de dilatação do trabalho de parto. Método: Estudo qualitativo, fundamentado nos princípios da Grounded Theory. Realizou-se 12 entrevistas com técnicas de enfermagem que assistiam parturientes em trabalho de parto no centro obstétrico de dois hospitais públicos de Florianópolis/SC, de agosto 2016 à março 2017. Os dados foram analisados através da codificação aberta e axial. Resultados: Para as técnicas de enfermagem a realização das boas práticas significa desempenhar sua função de forma adequada, proporcionar assistência humanizada à parturiente, respeitando sua autonomia, promover alívio da dor e um trabalho de parto mais tranquilo. Considerações Finais: recomenda-se a identificação do número adequado de técnicos para a manutenção da qualidade da assistência e a realização de registros de enfermagem de forma mais detalhada e sistematizada.

Descritores: Centros de Assistência à Gravidez a ao Parto; Enfermagem Obstétrica; Parto Humanizado; Trabalho de Parto; Humanização da Assistência.

\section{RESUMEN}

Objetivo: Identificar el significado que los técnicos de enfermería atribuyen a las buenas prácticas de cuidado basadas en evidencias científicas aplicadas a las parturientas durante la fase de dilatación del trabajo de parto. Método: Estudio cualitativo, basado en los principios de Grounded Theory. Se realizaron 12 entrevistas con técnicas de enfermería que asistieron a parturientas en trabajo de parto en el centro obstétrico de dos hospitales públicos de Florianópolis/SC, de agosto de 2016 a marzo de 2017. Los datos se analizaron a través de la codificación abierta y axial. Resultados: Para las técnicas de enfermería, aplicar las buenas prácticas significa desempeñar su función de forma adecuada, proporcionar asistencia humanizada a la parturienta, respetando su autonomía, promover alivio del dolor y un trabajo de parto más tranquilo. Consideraciones finales: Se recomienda la identificación del número adecuado de técnicos para el mantenimiento de la calidad de la asistencia y la realización de registros de enfermería de forma más detallada y sistematizada Descriptores: Centros de Asistencia al Embarazo y al Parto; Enfermería Obstétrica; Parto Humanizado; Trabajo de Parto; Humanización de la Atención. 


\section{INTRODUCTION}

The World Health Organization ${ }^{(1)}$ describes useful practices, based on scientific evidence, that should be encouraged during labor and delivery. The use of non-pharmacological and noninvasive pain relief methods are among these, such as: relaxation techniques, therapeutic shower bath, body massages, as well as audio-analgesia and aromatherapy.

The presence of a companion, chosen by the pregnant women, throughout labor and childbirth, provides encouragement and support during this period. It also helps with the management of non-pharmacological methods, which must be frequently and intensively offered. These are safe methods that provide pain and anxiety relief to the laboring parturient, contribute to a reduction in the use of invasive procedures, and enable the preservation of the physiology of childbirth ${ }^{(2-3)}$.

Providing good care practices is fundamental, as their absence makes labor even more uncomfortable and prolonged, turning this moment into a negative experience felt by the woman. In this sense, good care practices should be identified and used during childbirth; the meaning that the professionals who perform these practices attribute to them must also be known.

In view of the above, this study presents as a research question: what is the meaning that nursing technicians attribute to the good practices used with pregnant women during the labor dilatation stage?

This study was based on the academic experience of compulsory training performed during the sixth phase of the undergraduate nursing program, that was conducted in the labor, delivery and recovery (LDR) unit of a public maternity hospital, in the year 2015. It was possible to identify that some good care practices were not being used and/or were partially completed by some nursing technicians. Thus, a more detailed analysis on the subject was necessary, because the integration of good practices is of great importance, and can help to qualify care for the mother-child binomial.

\section{OBJECTIVE}

To identify the meaning that nursing technicians attribute to the good care practices, based on scientific evidence, used with pregnant women during the dilatation stage of labor.

\section{METHOD}

\section{Ethical aspects}

This study was conducted according to the determinations of Resolution 466/2012 of the National Health Council on research involving human beings ${ }^{(4)}$, and was approved by the Research Ethics Committees of the Federal University of Santa Catarina (UFSC) and Carmela Dutra Maternity of Santa Catarina, institutions where data collection was performed, and the Terms of Free and Informed Consent (TFIC) form was signed by the participants.

\section{Theoretical-methodological framework}

The Grounded Theory (GT) method, which is also called theory based on data, was originally and systematically developed during a study of terminally ill patients, by American sociologists Barney Glaser and Anselm Strauss at the University of California, USA, around 1965. Over time, Glaser and Strauss continued to work and develop the method, but they followed distinct paths, and each one tried to improve his version. The present study follows the Strauss version ${ }^{(5)}$.

\section{Type of study}

This was a qualitative study, which sought to understand the meaning that nursing technicians attribute to the good care practices used with pregnant women, during the dilation stage of labor.

\section{Methodological procedures}

The study was conducted based on the principles of theoretical sampling, as predicted by the method. A semi-structured interview script was developed with guiding questions, focusing on the use of good care practices, based on scientific evidence, provided to pregnant women in labor. The characteristics and amount of data that were collected, as well as the number of participants, were established by the researchers, during the research process.

\section{Place of study}

The study was conducted in two public maternity hospitals located in Florianópolis/SC, which in this study will be called hospital A and B. The LDR of hospital A accounted for approximately 250 deliveries monthly, and there were 22 nursing technicians during the data collection. Among these, two were on sick leave and two were on vacation. The LDR of this hospital also had 13 nursing assistants, of whom one was on sick leave and two were on vacation. On the other hand, the LDR of hospital B accounted for approximately 365 deliveries monthly, and had 25 nursing technicians during this period. Of these, six were on sick leave and one was on vacation. This LDR also had two nursing assistants, one of whom was on sick leave at the time of the data collection.

\section{Data collection and organization}

The data collection was performed from August of 2016 to March of 2017. Data collection was performed using a semi-structured interview with guiding questions, administered to nursing technicians working in the unit of the two maternity hospitals of Florianópolis/SC. These questions were related to the use of good scientific evidencebased care practices provided to pregnant women, such as: What do you understand as a good care practices during labor? Can you cite some examples of good care practice based on scientific evidence? Do you usually provide these practices in your daily activities? What is the meaning of good practices provided to pregnant women? Do you and your colleagues routinely provide non-pharmacological methods to pregnant women in your daily work? From your point of view, what are the non-pharmacological methods that are most effective or work better during labor?

Initially, in-depth interviews were administered to six nursing technicians of the LDR room from hospital A. Next, six nursing technicians from hospital B were interviewed, to obtain information from professionals working in the other institution, aiming 
to diversify the study site and participants. These interviews were audio recorded and transcribed for analysis, and were only conducted after the participants sign the TFIC.

The inclusion of the participants occurred in a random manner, because these professionals are more actively involved in care for the parturients in the dilation stage of labor. The fact that these professionals were in the workplace at the time of data collection was also considered, as well as the willingness of those professionals to voluntarily participate in the research. The reason for having only a female professional in the study is explained by the fact that research environment is filled, almost entirely, by women.

\section{Data analysis}

The data analysis was performed concomitantly with the data collection, and its evaluation led the collection process, until data saturation was achieved. Open and axial coding was performed in different, but integrated and complementary, phases ${ }^{(5)}$. In the open coding, each of the interviews was assessed line-by-line, and sentence-by-sentence, to separate data into distinct parts and to compare it constantly, searching for similarities and differences, in order to identify the emerging categories of data.

In the axial coding, the categories identified in the open coding were analyzed and classified, and the previously separated data were regrouped. The categories were associated with their respective subcategories to generate more precise explanations about them.

Data were analyzed as a whole, and study participants were identified by codenames, such as, NT1, NT2, NT3 ... and so on, where NT refers to the first letter of the words, nursing technicians, and the number indicates the order in which the interviews were performed.

\section{RESULTS}

Twelve nursing technicians with a variable service time, from one to 21 years of work with parturients in LDR of the two institutions, participated in the study. Five categories were developed based on these interviews: caring for the parturient in the labordelivery-recovery room; valuing the presence of the companion; personal and collective performance; management of nursing care performed by the nurse; and, the continuing education service. However, only the first category will be presented in this study.

The category, Caring for the parturient in the labor-delivery-recovery room, consisted of the following subcategories: Meaning of providing good care practices in LDR, according to the nursing technicians'points of view; using non-pharmacological methods during parturient care on a daily basis; perception of pregnant women about labor; relationship of the infrastructure with the accomplishment of the good care practices; and documenting the nursing care provided.

\section{Meaning of providing good care practices in the LDR unit according to the nursing technicians' points of view, using non-pharmacological methods during parturient care on a daily basis}

The nursing technicians stated that good practices provided to parturients have several meanings. According to them, good care practices during labor are non-pharmacological and non-invasive methods that respect the autonomy of the pregnant women and provide pain relief, by means of exercises, aiming for a peaceful labor. For them it is also to provide humanized care, and for all the women in LDR, including those experiencing abortion, who need attention in every dimension of care.

Another meaning of providing good practices stated by the interviewees was to demonstrate to the parturient that the professionals are not indifferent to the moment of pain, by helping her during her period of discomfort, which provides relief not only for the pregnant woman, but also for the nursing technicians. However, it has been mentioned that in providing good practice, to do and know how to do are not enough, but sensitivity, goodwill, and a good working environment are also necessary, which must be prepared with personal conditions to provide quality care to the parturients.

[...] Ah, I think that it is a relief for her and for us! As I told you ... It is very gratifying to see that you are helping the patient in some way... Because it is a difficult time! (NT8)

The interviewees considered that the use of good practices means obtaining a positive outcome, aiming to provide the parturients with well-being. The achievement of a favorable outcome, by means of non-pharmacological methods, provides a sense of professional fulfillment to the nursing technicians. In addition to helping in the evolution of labor, good practices often prevent the pregnant women from undergoing surgical intervention, as in the case of caesarean section, according to the statement:

\begin{abstract}
... You see that it really worked! What you provide to the patient was good for her! And sometimes, what you do, often, prevents the patient undergoing a cesarean delivery... A surgical intervention! I believe that sometimes, many patients undergo a surgery because this is not offered to her! Something like that, which makes it evolve! Sometimes you leave the patient, for example, very immobilized ... You do not invest in the patient ... And she develops a prolonged labor! (NT6)
\end{abstract}

The nursing technicians stated that they provide good care practices, including non-pharmacological methods that work to relieve labor pain in parturients, according to the guidance of a skilled professional, nurse or physician. In addition, they consider it necessary to provide individualized assistance, in order to identify the non-pharmacological methods that the parturients prefer, according to the stage of labor in which they are found.

\section{Perception about the parturients in labor}

The participants believe that welcoming is fundamental and primordial during labor, and that welcoming the parturient means to explain to her everything that will be done. Thus, the interviewees stated the importance of knowing how to receive the anxious parturient in an environment that is unknown, and filled with strangers. In addition, to introduce themselves to the parturient is also a good care practice provided during labor, which provides a peaceful atmosphere.

Emotional support was also identified as a good care practice, and one form of care they need most right now. In the same way, respect for the parturients, because according to the interviewees, 
it is also necessary to understand their decision to not adhere to good practices and to the non-pharmacological methods for pain relief, respecting their choices and empowering them in their singularities and protagonism in labor.

[...] What they need most in that moment is the psychological support! Having someone there, at her side, so they can look to a face ... can hold a hand... and someone that instructs them on what they have to do! (NT8)

\section{Relationship of the infrastructure with the accomplish- ment of good care practices and documenting the nursing care provided}

For nursing technicians, keeping the environment with proper lighting, i.e., a little darker, is also a good care practice during labor, as well as reducing the number of people circulating in the room. The interviewees stated that preserving the woman's privacy with her partner is a good practice, however, professionals should be with them, whenever necessary, offering support and guidance.

Remaining with the parturient and her partner was stated as a good care practice. Similarly, there was proper breathing orientation, because it helped in the self-control of pregnant women during labor, as well as the incentive to listen to some music of their choice.

The interviewees stated that the use of the Pilates ball has the purpose of helping in the dilation of the uterine cervix, and acceleration of labor due to gravity, and is a good care practice. According to the participants, the exercises with the Pilates ball are usually performed circular, forward, backward, and to the sides.

The technicians interviewed mentioned that massage is also an important good care practice, and works for pain relief, as long as the parturient can relax and release the hips. They stated that massage is performed whenever possible, and according to the parturient needs, however, sometimes nurses cannot perform this, due to the number of staff members in the sector. Some participants found massage to be the most effective and best-performing method during labor, as it provides a sense of relief and relaxation. According to those interviewed, massages requires at least 20 to 25 minutes, as it is also necessary to calm, cherish, and talk quietly with the parturient.

Performing proper positioning of the parturient, as well as encouraging the use of the "little horse" and the "stool" were also stated by the participants as a good care practice during labor. In addition, orienting the parturients on ambulation and hip movement are also qualified practices pondered by the interviewees.

The interviewees also stated the maintenance of parturient hygiene in bed was a good practice of care that aimed for comfort, which is obtained using the hygienic bath.

In turn, they said that offering and referring the woman to the therapeutic bath is also a good care practice performed during labor, as it helps to calm both the woman and the fetus, facilitating the evolution of the labor. Most of the interviewees considered therapeutic bath as the most effective method that works because it relieves pain, accelerates the labor, provides comfort and relaxation, and reduces tension.

Some participants considered that the parturients should not be cared for in the same way, because each one has their own particularities and preferences. During labor, the emotional side is the most affected, as this is a conflicting moment, and the parturients arrive in LDR very anxious, and sometimes the multiparous are more anxious than the nulliparous ones.

According to the participants, the prenatal care presents gaps, because the parturients arrive in LDR very frightened, and without previous knowledge about labor and delivery. Therefore, according to them, prenatal care could certainly contribute to the quality of care in the process of parturition.

[...] the prenatal care does not prepare her for anything ... She arrives here, very anxiously in a totally hospital environment ... And when she arrives I want to explain to her that she has to find an appropriate position! A comfortable position, regardless of what shape it is! That she has the right to a companion; that the baby will always be at her side. And, why we do not bathe the baby in the first hour! (NT9)

The nursing technicians interviewed considered that documentation of good care practices in the parturients' records is important to evaluate the effectiveness of the methods used for pain relief, as well as for the Stork Network program. However, they recognized that it is imperfect because it is simple and direct, and that it should register all the information. However, they mentioned that only the admission documentation is performed satisfactorily.

\section{DISCUSSION}

The participants of the present study stated several meanings for good care practices, and these aim to provide the protagonism and well-being of the parturients, pain relief, and a more serene delivery.

In the same way, a study conducted in Santa Maria/RS, between April and July of 2016, with 27 health professionals from an obstetric unit, concluded that good practices stimulate the role of women in their multiple dimensions and, more than that, contribute to rethinking the model of obstetric care in Brazil, as well as contribute to organizing the maternal and child health care network, aiming at access, welcoming, and resolution ${ }^{(6)}$.

The study showed that, for the nursing technicians, good care practices means humanized care, provided to the parturients in a singular and multidimensional manner. The implementation of practices aimed at the autonomy and empowerment of the pregnant women during labor requires humanized and qualified obstetric care $^{(7)}$. Among the practices mentioned by the authors are: welcoming, encouragement of the parturient's autonomy, promotion of the partner's presence, and an adequate environment, among others.

Humanized care during labor, focused on the women, provides several benefits related to the social, cultural, and emotional aspects of parturients, as well as to indicators of morbidity and mortality ${ }^{(8)}$. In this way, qualified care should be individualized and flexible, aiming to provide feelings of safety and protection with the health team.

The study showed that, for those interviewed, the use of good care practices provides satisfaction, personal and professional fulfillment, gratification, and demonstrates to the parturients that the professionals care about them. In addition, it was also emphasized that it is not enough to provide and know how to do provide, or even performing the practices routinely; it requires sensitivity with parturients, goodwill, and a favorable work environment, personal conditions to provide good care and be prepared to perform their actions. 
A study was conducted with the objective of understanding the practices provided by health professionals in the care to the parturient ${ }^{(9)}$. The authors concluded that the professionals who provide this care are sensitized to the parturients' peculiarities; provide a qualified and humanized obstetric care, encouraging the parturients' autonomy during the labor.

This study showed that several good practices are performed in the two maternity units during the labor dilation stage, including non-pharmacological methods, such as massage, therapeutic bath, Pilates ball, stool, little horse, guided breathing, less brightly lit rooms, directions, music, and others. The therapeutic bath was felt to works best, among the best practices.

An intervention study conducted in a maternity ward of Itapecerica da Serra/SP, with 50 mothers and 102 clinical records, from July to November of 2014, identified barriers and difficulties for implementation of evidence-based practices. However, a significant increase in the use of bath, ambulation, and massage for pain relief was verified ${ }^{(10)}$.

The use of non-pharmacological methods for pain relief during the active stage of labor, performed in a combined or isolated manner, deals with safe and practical strategies that reduce pain and anxiety by promoting comfort and well-being ${ }^{(11)}$. According to the same authors, the benefits of these practices demonstrate that it should be stimulated and encouraged by professionals during labor.

According to the Ministry of Health ${ }^{(12)}$ a survey that evaluated the quality of the services provided and the degree of satisfaction of the women receiving care in the Unified Health System (SUS) in the pregnancy- postpartum period, aged between 10 and 50 years, totaling 42,638 women, was conducted between 2012 and 2013. Less than one-third were fed during labor, and used nonpharmacological procedures for pain relief, about $45 \%$ of them reported mobility during labor. However, the use of good practices showed a varied prevalence, generally $<50 \%$ of pregnant women.

This study demonstrated that nursing technicians cannot always remain with the pregnant woman during labor, due to the insufficient number of professionals in LDR, which compromises the continuous care. Some of the reasons given for the reduced number of nursing technicians in LDR are lack of hiring and absenteeism.

Our study showed that participants integrate the companions in the accomplishment of the non-pharmacological methods for pain relief, using this as a strategy of involvement and sensitization of the partner to participate in the birth moment. This practice is ideal, and recommended when describing that LDR professionals should seek tactics for integrating the father/partner in labor and delivery, with the purpose of acting in the birth process, benefiting the partner, the pregnant woman, and the baby ${ }^{(13)}$.

In general, the study showed that the majority of the pregnant women arrive in LDR without previous preparation for experiencing labor and delivery. This training should be performed during the prenatal period, however, there are still some things lacking in this sense, and the parturients are anxious and confused about the subsequent stages through which she will progress, mainly due to a lack of knowledge about how labor occurs. The fact that the multiparous women are more anxious than the nulliparous ones is probably related to their previous experiences, in previous births, which may have been traumatic.

An observational, descriptive, cross-sectional study with a sample of 62 women comparing a sample of primiparous pregnant women with a group of multiparous women, regarding maternal prenatal attachment to the fetus, anxiety in pregnancy, and quality of the marital relationship, showed that the quality of the positive conjugal relationship differs between the multiparous and the primiparous, with more positive aspects being evident in the conjugal relationship of primiparous women ${ }^{(14)}$. This study also found that the multiparous women presented greater anxiety symptomatology than the primiparous ones.

The present research demonstrated that documentation is considered important by the interviewees. However, it has also been found that they appear to be inconsistent, due to the lack of annotation regarding procedures performed, which when realized, are very succinct and direct. In general, the parturients' admission to LDR is satisfactorily documented, however the other information is not fully and frequently documented. The best practice recorded in the medical record is the therapeutic bath. This lack of complete and continuous documentation impairs the visualization and evaluation of the effectiveness of the non-pharmacological methods for pain relief.

A study found in Brazilian journals that aimed to analyze the nursing records, described that a failure of documentation could provide serious consequences for care ${ }^{(15)}$. Therefore, the authors consider the nursing records essential in relation to care provided, as it provides visualization of relevant information.

As the nursing technicians do not record in a standardized manner, the communications of good practices already performed to the other members of the LDR team are compromised, as well as the sequence of the care provided. These findings demonstrate that nurses and healthcare professionals need to be more committed to good practices through the involvement of the entire multiprofessional team, which can contribute to the paradigm changes in the obstetric scenario, and the possibility of transformation of the current obstetric system model ${ }^{(6)}$.

\section{Study limitations}

The study presents as a limitation the size of the sample, and it only includes two public institutions in Florianópolis city, not considering other realities in this context. The use of good practices is in line with public policies, which aim at humanization and quality of care, and should be extended to other Brazilian regions in order to implement obstetric experiences.

\section{Contributions to the nursing field}

The results demonstrate relevant contributions to nursing, as they corroborate the importance of the adequate staffing of technicians in LDR, while recognizing good practices in labor and delivery, enabling more humanized care, and offering a higher quality of care, identifying the individual needs of each pregnant woman, and empowering them as protagonists of their own birth.

\section{FINAL CONSIDERATIONS}

The results of this study revealed the meaning that nursing technicians attribute to the accomplishment of good practices in the care of pregnant women, as well as demonstrate which good care practices are performed by them. 
For nursing technicians, the implementation of good practices means performing activities adequately and providing humanized care to the pregnant woman, respecting her autonomy during labor. They have skills and knowledge related to good practices, and according to their statements, they understand the importance, consequences, and indications of good practices that can be performed in the institutions in which they work.

This research provided a picture of the fundamental performance of the nursing technicians to promote the quality of care in a humanized manner, and they should invest in the accomplishment of good practices for the parturients welfare.

Finally, adequate staffing must be accomplished, identifying the adequate number of nursing technicians needed to maintain the quality of care in LDR. Nursing documentation in a more detailed and systematized manner is recommended, aiming at visualizing the performance of nursing care.

\section{ACKNOWLEDGMENT}

The authors thank the Conselho Nacional de Desenvolvimento Científico e Tecnológico (National Council for Scientific and Technological Development) - (CNPq), for financial support, through the Call Notice MCTI/CNPQ/Universal 14/2014. They also thank the Coordenação de Aperfeiçoamento de Pessoal de Nível Superior (Coordination of Improvement of Higher Education Personnel - (CAPES) for the support received.

\section{REFERENCES}

1. Ministério da Saúde (BR). Secretaria de Ciência, Tecnologia e Insumos Estratégicos. Departamento de Gestão e Incorporação de Tecnologias em Saúde. Diretrizes nacionais de assistência ao parto normal[Internet]. Brasília. 2017 [cited 2018 Mar 23]. Available from: https://bvsms. saude.gov.br/bvs/publicacoes/diretrizes_nacionais_assistencia_parto_normal.pdf

2. Osório SMB, Silva Jr LG, Nicolau AIO. [Assessment of the effectiveness of non-pharmacological methods in pain relief during labor]. Rev Rene [Internet]. 2014 [cited 2016 May 13];15(1):174-84. Available from: https://www.revistarene.ufc.br/revista/index.php/revista/article/view/1372 Portuguese.

3. Souza SRRK, Gualda DMR. [The experience of women and their coaches with childbirth in a public maternity hospital]. Texto Contexto Enferm. [Internet]. 2016 [cited 2018 May 22];25(1):e4080014. Available from: http://dx.doi.org/10.1590/0104-0707201600004080014. Portuguese

4. Ministério da Saúde (BR). Conselho Nacional de Saúde. Resolução № 466, de 12 de dezembro de 2012. Aprova diretrizes e normas regulamentadoras de pesquisas envolvendo seres humanos [Internet]. 2013 [cited 2017 Apr 02]. Available from: https://www.conselho. saude.gov.br/resolucoes/2012/Reso466.pdf

5. Strauss A, Corbin J. Pesquisa qualitativa: técnicas e procedimentos para o desenvolvimento de teoria fundamentada. 2. ed., Porto Alegre: Artmed; 2008.

6. Pereira SB, Diaz CMG, Backes MTS, Ferreira CLL, Backes DS. Good practices of labor and birth care from the perspective of health professionals. Rev Bras Enferm. 2018;71(Suppl 3):1313-9. doi: 10.1590/0034-7167-2016-0661

7. Silva ALS, Nascimento ER, Coelho EAC. Nurses practices to promote dignity, participation and empowerment of women in natural childbirth. Esc Anna Nery [Internet]. 2015 [cited 2017 Jun 20];19(3):424-31. Available from: http://dx.doi.org/10.5935/1414-8145.20150056

8. Medeiros RMK, Teixeira RC, Nicolini AB, Alvares AS, Corrêa ACP, Martins DP. Humanized Care: insertion of obstetric nurses in a teaching hospital. Rev Bras Enferm [Internet]. 2016 [cited 2018 May 21];69(6):1091-8. Available from: https://www.scielo.br/pdf/reben/v69n6/00347167-reben-69-06-1091.pdf

9. Melo LPT, Doudou HD, Rodrigues ARM, Silveira MAM, Barbosa EMG; Rodrigues DP. [Practices of health professionals in delivery and birth care]. Rev Rene [Internet]. 2017 [cited 2017 Jun 20];18(1):59-67. Available from: https://periodicos.ufc.br/index.php/rene/article/ viewFile/18870/29603 DOI: 10.15253/2175-6783.2017000100009. Portuguese

10. Côrtes CT, Santos RCS, Caroci AS, Oliveira SG, Oliveira SMJV, Riesco MLG. [Implementation methodology of practices based on scientific evidence for assistance in natural delivery: a pilot study]. Rev Esc Enferm USP [Internet]. 2015 [cited 2018 Jun 03];49(5):716-25. Available from: https://www. scielo.br/pdf/reeusp/v49n5/pt_0080-6234-reeusp-49-05-0716.pdf http://dx.doi.org/10.1590/S0080-623420150000500002. Portuguese

11. Barbieri M, Henrique AJ, Chors FM, Maia NL, Gabrielloni MC. [Warm shower aspersion, perineal exercises with Swiss ball and pain in labor]. Acta Paul de Enferm [Internet]. 2013 [cited 2017 Apr. 25];26(5):478-84. Available from: http://dx.doi.org/10.1590/S010321002013000500012. Portuguese

12. Ministério da Saúde (BR). Secretaria de Vigilância em Saúde. Departamento de Vigilância de Doenças e Agravos Não Transmissíveis e Promoção da Saúde. Saúde Brasil 2015/2016: uma análise da situação de saúde e da epidemia pelo vírus Zika e por outras doenças transmitidas pelo Aedes aegypti. Brasília: Ministério da Saúde, 2017.

13. Carvalho CFS, Carvalho IS, Brito RS, Vitor AF, Lira ALBC. [The partner as a caregiver in the birth process]. Rev Rene [Internet]. 2015 [cited 2017 Sep 09];16(4):613-21. Available from: https:www.revistarene.ufc.br/revista/index.php/revista/article/download/2019/pdf Portuguese

14. Magalhães CSP. [Anxiety, quality of the conjugal relationship and maternal bond to the fetus: a study with primiparous and multiparous pregnant women]. [Dissertation]. Faculdade de Filosofia. Universidade Católica Portuguesa. 2013 [cited 2017 Jun 30]. Available from: https://repositorio.ucp.pt/handle/10400.14/13745. Portuguese

15. Claudino HG, Gouveia EML, Santos SR, Lopes MEL. [Audit in nursing records: integrative review in the literature]. Rev Enferm UERJ [Internet]. 2013 [cited 2017 Apr 25];21(3):397-402. Available from: https://www.facenf.uerj.br/v21n3/v21n3a20.pdf Portuguese 